\title{
REAKSI PASAR MODAL TERHADAP PENGUMUMAN PEROMBAKAN (RESHUFFLE) TERBATAS KABINET INDONESIA BERSATU Studi Empiris pada Perusahaan-perusahaan yang Terdaftar di Bursa Efek Jakarta (BEJ)
}

\author{
C. Wahyu Estining Rahayu \\ Fakultas Ekonomi Universitas Sanata Dharma
}

\begin{abstract}
This research analyzes capital market' reaction to announcements of limited reshuffle of Indonesian Cabinet (Kabinet Indonesia Bersatu) in Jakarta Stock Exchange (JSX). The announcements is full of political events, that is information of joining Boediono in the cabinet (duet with Sri Mulyani Indrawati), which is being predicted to be able to solve nation's economic problems today. This research hypothesizes that the capital market reacts positively to the announcements of limited reshuffle of Indonesian Cabinet (Kabinet Indonesia Bersatu).

A sample of 45 firms, which are included in LQ 45 category, are all fulfilling liquidity and market capitalization criteria. Research period consists of estimation period and event period, from September 30th, 2005 until December 19th, 2005. An event study technique is employed to analyze capital market' reaction to announcements of limited reshuffle.

The study documented that there is a significant positive abnormal return (used as a proxy of capital market' reaction) surrounding the announcement date, which is before and after the announcements of limited reshuffle. The positive capital market' reaction deal with signaling theory, that is the announcements of limited reshuffle tend to be articulated as a signal of belief' shareholders to SBY - JK performance (which is representated by the new economic team, between Boediono, as a Economic Coordinator Minister and Sri Mulyani Indrawati, as a Financial Minister) today and the future.
\end{abstract}

Key words: abnormal return, limited reshuffle announcement, reaksi pasar modal

\section{PENDAHULUAN}

Latar Belakang Masalah

Menurut Undang-undang Republik Indonesia Nomor 8 Tahun 1995 pasar modal memiliki peran yang strategis dalam bidang pembangunan nasional, yaitu sebagai salah satu sumber pembiayaan bagi dunia usaha dan wahana investasi bagi masyarakat (dikutip dalam Rustamadji, 2001: 36). Sebagai salah satu instrumen perekonomian maka pasar modal tidak terlepas dari pengaruh yang berkembang di lingkungannya, baik yang terjadi di lingkungan ekonomi maupun di lingkungan non ekonomi. Salah satu lingkungan non ekonomi yang berkaitan erat dengan lingkungan ekonomi adalah lingkungan politik. Hal ini disebabkan karena peristiwa politik akan pula mempengaruhi gejolak di pasar modal.

Salah satu peristiwa politik yang penting yang diinformasikan kepada publik dalam bentuk pengumuman melalui berbagai media, akan diuji dalam penelitian ini yaitu pengumuman perombakan anggota kabinet terbatas yang tergabung dalam Kabinet Indonesia Bersatu. Pengumuman perombakan (reshuffle) ini diumumkan 
Presiden Susilo Bambang Yudhoyono (SBY) di Gedung Agung Yogyakarta pada hari Senin tanggal 5 Desember 2005 pukul 21.00 setelah Presiden melakukan evaluasi terhadap kinerja kabinetnya selama satu tahun. Tiga nama baru masuk kabinet, tiga menteri diberhentikan, dan tiga menteri dirotasi. Adapun tiga nama baru yang bergabung dengan Kabinet Indonesia Bersatu adalah: Pertama, Boediono, ditunjuk sebagai Menteri Koordinator Perekonomian menggantikan Aburizal Bakrie yang kini menjadi Menteri Koordinator Kesejahteraan Rakyat; Kedua, Paskah Suzetta, ditunjuk menjadi Menteri Negara Perencanaan Pembangunan Nasional/Kepala Bappenas menggantikan Sri Mulyani Indrawati yang kini menjadi Menteri Keuangan; Ketiga, Erman Suparno, dipercaya sebagai Menteri Tenaga Kerja dan Transmigrasi menggantikan Fahmi Idris yang digeser menjadi Menteri Perindustrian. Sedangkan tiga nama yang keluar dari kabinet adalah Jusuf Anwar (Menteri Keuangan), Alwi Shihab (Menko Kesra), dan Andung Nitimihardja, selaku Menteri Perindustrian (Suara Pembaruan, 11 Desember 2005).

Munculnya pengumuman yang berisi informasi tentang masuknya Boediono dalam kabinet (yang duet bersama Sri Mulyani Indrawati), ditanggapi secara positif oleh sejumlah pengamat, pelaku pasar uang dan pasar modal serta kalangan dunia usaha, bahkan pihak IMF (International Monetary Fund) karena mereka dianggap mampu memberikan harapan dalam mewujudkan perekonomian yang lebih baik di masa mendatang (Sari Suara Indonesia, 6 Desember 2005). Hal ini menandakan bahwa pengumuman tersebut memberi sinyal kepada pasar bahwa kinerja tim ekonomi yang baru dianggap lebih baik dalam menyelesaikan masalah ekonomi saat ini. Setelah menerima sinyal melalui pengumuman tersebut maka pasar akan bereaksi. Reaksi pasar ini dapat diartikan bahwa pasar menangkap informasi tentang prospek kinerja tim ekonomi yang baru yang terkandung dalam pengumuman tersebut. Namun masalah yang muncul adalah bagaimanakah reaksi pasar modal, yang dicerminkan melalui perubahan harga saham di BEJ, terhadap pengumuman perombakan (reshuffle) terbatas Kabinet Indonesia Bersatu? Adapun penelitian ini bertujuan untuk menguji secara empiris bagaimanakah reaksi pasar modal, yang dicerminkan melalui perubahan harga saham, terhadap pengumuman perombakan (reshuffle) terbatas Kabinet Indonesia Bersatu.

\section{TINJAUAN LITERATUR}

\section{Reaksi Pasar Modal terhadap Peng- umuman Peristiwa Politik}

Menurut Sulistyanto dan Prapti

(2003) penelitian tentang pengaruh suatu pengumuman baik informasi keuangan maupun informasi non keuangan terhadap respon pasar telah banyak dilakukan oleh beberapa peneliti keuangan seperti Ball dan Brown (1968), Bamber (1986), Beza (1997), Choi (2002), Frazier et al (1984), Ferere dan Renneboog (2000), Chen (2001), dan Durtschi et al (2002). Selanjutnya penelitian studi peristiwa tentang pengaruh suatu pengumuman, khususnya pengumuman yang bermuatan politik, terhadap respon pasar untuk kasus-kasus di Bursa Efek Indonesia (khususnya di Bursa Efek Jakarta) telah dilakukan pula oleh beberapa peneliti Indonesia.

Di Indonesia penelitian tentang pengumuman yang bermuatan politik sudah pernah dilakukan oleh beberapa peneliti sebelumnya, dan memberikan hasil yang cenderung konsisten. Asri (1996), Suryawijaya dan Setiawan (1998), Nugroho (1999), Nunuhitu (1999), Hidayat (1999), Kurnia (2001), Rustamadji (2001), dan Gunawan (2004) menyimpulkan bahwa ada reaksi pasar yang positif dan signifikan bila pengumuman tentang peristiwa politik 
tersebut diharapkan oleh pasar. Namun sebaliknya apabila pengumuman tersebut tidak diharapkan oleh pasar maka pasar akan bereaksi negatif dan signifikan.

Signaling Theory Berkaitan dengan Pengumuman Perombakan (reshuffle) Terbatas Kabinet Indonesia Bersatu

Hartono (2000: 32) berpendapat bahwa salah satu faktor yang dapat meningkatkan aktivitas di pasar modal adalah peristiwa politik yang informasinya dipublikasikan dalam bentuk pengumuman melalui berbagai media. Peristiwa politik yang diharapkan sejumlah kalangan ini, yaitu pengumuman perombakan (reshuffle) terbatas Kabinet Indonesia Bersatu, dilakukan Presiden SBY dalam rangka menciptakan stabilitas ekonomi, mendorong pertumbuhan ekonomi, dan menggerakkan sektor riil. Peristiwa ini merupakan petunjuk (signal) bagi para pelaku di pasar modal bahwa pemerintah Indonesia mampu menyelesaikan masalah ekonomi secara lebih baik, lebih cepat, dan lebih tepat. Hal ini akan mempengaruhi kepercayaan para pelaku di pasar modal terhadap pemerintah Indonesia. Sebagai akibatnya aktivitas di pasar modal kembali meningkat, dan ini akan ditunjukkan dengan adanya perubahan harga saham. Bukti empiris dalam penelitian Nunuhitu (1999) juga menunjukkan bahwa pasar modal bereaksi positif terhadap peristiwa politik yang diharapkan, yaitu pengumuman Rancangan Anggaran Pendapatan Belanja Negara (RAPBN) pada tanggal 6 Januari 1998. Hal ini dibuktikan dengan munculnya positive abnormal return yang signifikan pada hari ke 6,7 , dan 8 sesudah pengumuman.

Dengan demikian menurut signaling theory pasar akan cenderung menginterpretasikan peristiwa reshuffle sebagai sinyal perbaikan kinerja pemerintah saat ini maupun prospeknya di masa mendatang. Sinyal ini pada akhirnya akan mem- pengaruhi aktivitas di pasar modal (dicerminkan oleh pergerakan harga saham) sehingga pada akhirnya pasar modal akan bereaksi positif terhadap pengumuman yang diharapkan tersebut. Penelitian Nunuhitu (1999) mendukung signaling theory ini.

\section{Perumusan Hipotesis}

Hartono (2000: 318) mengemukakan bahwa studi tentang kandungan informasi bertujuan untuk melihat kandungan dari suatu peristiwa yang terjadi. Suatu peristiwa dikatakan memiliki kandungan informasi bila peristiwa tersebut terdapat abnormal return. Pasar akan bereaksi atau abnormal return akan muncul pada saat pengumuman diinformasikan.

Kandungan informasi menyatakan bahwa peristiwa politik yang diharapkan pasar menginformasikan kepada pasar tentang pandangan mereka terhadap prospek perekonomian negara di masa mendatang. Perubahan dalam keputusan politik mengandung informasi yang mampu membuat pelaku pasar modal merubah prediksi mereka tentang prospek perekonomian di masa yang akan datang. Hal ini akan membawa akibat bagi pasar modal di mana terdapat penyesuaian harga saham ketika kebijakan politik diumumkan. Kandungan informasi ini didasarkan pada signaling theory. Apabila suatu penelitian tentang pengumuman peristiwa politik mendukung signaling theory maka dapat diartikan bahwa pengumuman tersebut memiliki kandungan informasi.

Pengumuman perombakan (reshuffle anggota kabinet terbatas muncul pada saat bangsa Indonesia sedang menghadapi masalah ekonomi yang cukup berat. Dengan masuknya Boediono sebagai salah satu anggota tim ekonomi yang baru ke dalam Kabinet Indonesia Bersatu ternyata ditanggapi secara positif oleh sejumlah kalangan. Hal ini disebabkan karena tim ekonomi tersebut dianggap mampu memberikan harapan 
dalam mewujudkan perekonomian yang lebih baik. Dengan demikian tanggapan sejumlah kalangan ini diduga juga menunjukkan reaksi pasar modal yang signifikan terhadap pengumuman tersebut, yang dicerminkan oleh abnormal return yang signifikan di sekitar tanggal pengumuman.

Berdasarkan uraian tersebut maka rumusan hipotesis dalam penelitian ini adalah: "Pasar modal bereaksi positif terhadap pengumuman perombakan (reshuffle) terbatas Kabinet Indonesia Bersatu".

\section{METODE PENELITIAN \\ Populasi dan Penentuan Sampel}

Populasi dalam penelitian ini adalah seluruh perusahaan yang terdaftar di Bursa Efek Jakarta (BEJ) pada saat periode penelitian, 30 September - 19 Desember 2005. Jumlah seluruh perusahaan yang terdaftar di BEJ pada saat periode penelitian ada 321 , baik yang bergerak dibidang manufaktur maupun jasa. Sedangkan sampel yang digunakan dalam penelitian ini yaitu 45 perusahaan yang tergabung dalam kelompok saham LQ 45. Hal ini dilakukan karena 45 perusahaan tersebut merupakan perusahaan yang memenuhi kriteria likuid dan kapitalisasi pasar sebagaimana ditetapkan oleh BEJ. Hal ini dapat diartikan bahwa ke-45 saham tersebut mampu mengakomodasi likuiditas transaksi saham-saham di BEJ dan mampu mengkapitulasi pasar sekitar 72\% dari total kapitulasi pasar BEJ. Dengan demikian pergerakan transaksi yang terjadi pada saham-saham tersebut dapat mewakili secara keseluruhan aktivitas di BEJ.

\section{Pengumpulan dan Pengolahan Data}

Data yang digunakan dalam penelitian ini adalah data sekunder, yang berupa harga saham harian LQ 45, Indeks Harga Saham Gabungan (IHSG) harian, dan tanggal pengumuman peristiwa politik. Data-data tersebut diperoleh dari BEJ, khususnya dari websitewww.jsx.com, dan Capital Market Directory.

\section{Penentuan Periode Peristiwa dan Periode Estimasi}

Tanggal 5 Desember 2005 yang dianggap sebagai event pengumuman ditetapkan sebagai t 0 . Kemudian berdasarkan tanggal tersebut ditentukan kisaran 10 hari sebelum peristiwa $(\mathrm{t}-10)$ dan 10 hari sesudah peristiwa $(\mathrm{t}+10)$ sebagai event period (periode peristiwa) atau window period (periode jendela) sehingga periode jendela ada 21 hari bursa. Periode estimasi (estimation period) yang dipakai dalam penelitian ini adalah 30 hari (sejak $\mathrm{t}-40$ sampai dengan $\mathrm{t}-11$ ), dan digunakan untuk mengestimasiexpected return saham.

\section{Pengujian Hipotesis}

Hipotesis yang akan diuji dalam penelitian ini adalah ada reaksi pasar modal terhadap pengumuman perombakan (reshuffle terbatas Kabinet Indonesia Bersatu. Pengujian ini dilakukan dengan event study, yang digunakan untuk menguji "apakah terdapat abnormal return" yang signifikan pada saat pengumuman tersebut dikeluarkan. Event study digunakan untuk menguji reaksi pasar modal yang signifikan terhadap pengumuman tentang peristiwa penting. Reaksi pasar modal ini diproksikan oleh abnormal return $(A R)$ yang terjadi selama event period (periode peristiwa).

\section{ANALISIS DATA}

Adanya abnormal return yang signifikan selama periode peristiwa menunjukkan bahwa pasar modal bereaksi terhadap pengumuman perombakan (reshuffle) terbatas Kabinet Indonesia Bersatu. Agar dapat memperoleh abnormal return selama periode peristiwa maka ada beberapa tahap yang harus dilakukan yaitu:

1. Menghitung average actual return saham harian untuk seluruh sampel 
selama periode peristiwa dan gambar grafik yang menunjukkan pola pergerakannya.

Berdasarkan Tabel 1, terdapat average actual return saham LQ 45 yang bernilai positif dan negatif selama periode peristiwa. Nilai positif average actual return menunjukkan adanya peningkatan harga saham pada hari ke $t$ dari harga saham pada hari ke t -1 . Sedangkan nilai negatif average actual return menunjukkan harga saham pada hari ke $\mathrm{t}$ lebih rendah dibandingkan dengan harga pada hari ke $\mathrm{t}-1$.

Tabel 1: Hasil Perhitungan Average Actual Return Saham Harian di sekitar Tanggal Pengumuman

\begin{tabular}{|c|c|c|c|c|c|}
\hline \multicolumn{2}{|c|}{ Sebelum Peristiwa } & \multicolumn{2}{|c|}{ Saat Peristiwa } & \multicolumn{2}{c|}{ Sesudah Peristiwa } \\
\hline Hari ke & AActR & Hari ke & AActR & Hari ke & AActR \\
\hline $\mathrm{T}-10$ & 0,0084 & $\mathrm{t} 0$ & $-0,0059$ & $\mathrm{t}+1$ & 0,0066 \\
$\mathrm{t}-9$ & 0,0055 & & & $\mathrm{t}+2$ & 0,0282 \\
$\mathrm{t}-8$ & $-0,0017$ & & & $\mathrm{t}+3$ & 0,0031 \\
$\mathrm{t}-7$ & 0,0122 & & & $\mathrm{t}+4$ & 0,0076 \\
$\mathrm{t}-6$ & $-0,0050$ & & & $\mathrm{t}+5$ & 0,0182 \\
$\mathrm{t}-5$ & 0,0024 & & & $\mathrm{t}+6$ & 0,0062 \\
$\mathrm{t}-4$ & $-0,0004$ & & & $\mathrm{t}+7$ & $-0,0102$ \\
$\mathrm{t}-3$ & 0,0111 & & & $\mathrm{t}+8$ & $-0,0177$ \\
$\mathrm{t}-2$ & 0,0062 & & & $\mathrm{t}+9$ & $-0,0067$ \\
$\mathrm{t}-1$ & 0,0294 & & & $\mathrm{t}+10$ & 0,0172 \\
\hline
\end{tabular}

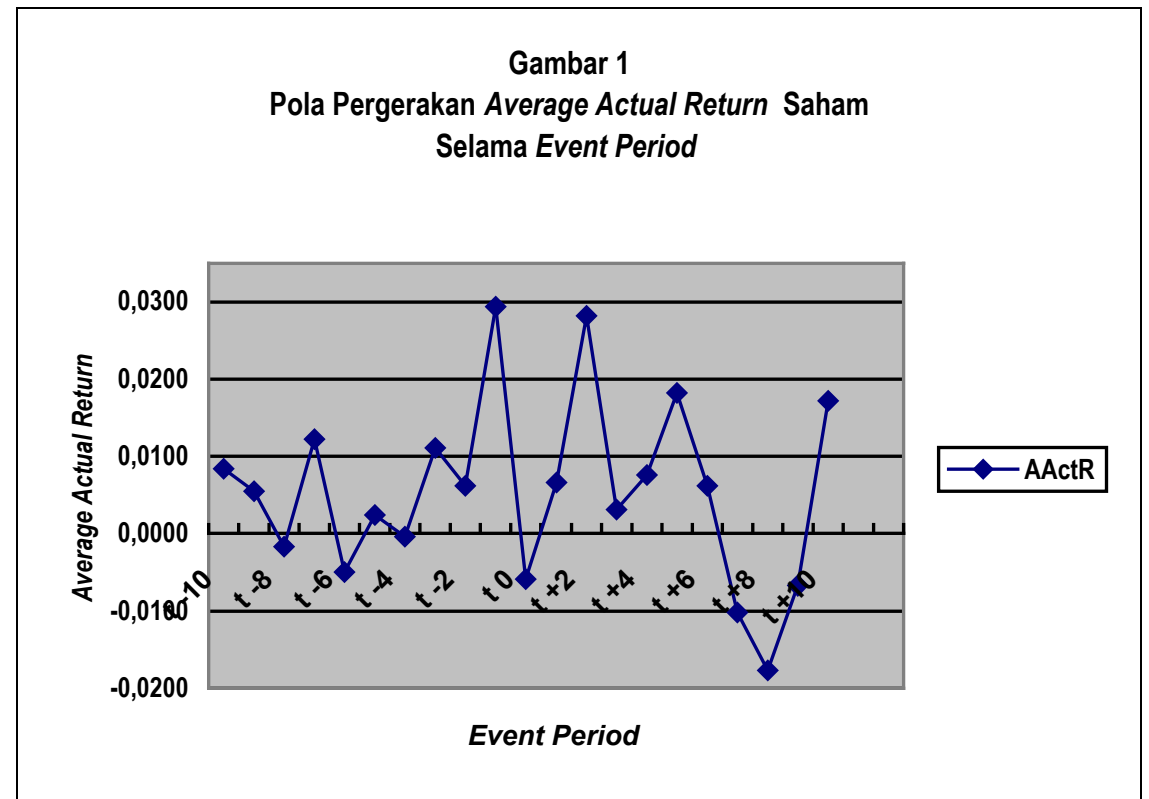


SIIERGHI Vol. 9 No. 2, JUNI 2007: 129 - 142

Gambar 1 memperlihatkan pergerakan average actual return selama periode peristiwa. Secara umum grafik tidak menunjukkan gejolak yang berarti, dan kondisi ini dilatarbelakangi oleh sikap menunggu para investor tentang keputusan perombakan (reshuffle) anggota kabinet terbatas oleh Presiden. Gejolak mulai tampak pada $\mathrm{t}-3$ dan $\mathrm{t}-1$ yaitu average actual return meningkat tajam dari -0,0004 ( $\mathrm{t}-4)$ menjadi 0,0111 (t -3), dan dari 0,0062 (t -2) menjadi $0,0294(\mathrm{t}-1)$. Hal ini mengindikasikan bahwa meskipun keputusan perombakan anggota kabinet terbatas baru akan disampaikan pada tanggal 5 Desember 2005 (t 0) tetapi para investor telah dapat mengetahui informasi ini sebelumnya dan mereka melakukan aksinya dengan membeli saham. Namun pada saat Presiden menyampaikan pengumuman ( $t \quad 0)$ terjadi penurunan grafik yang sangat tajam. Hal ini menunjukkan bahwa pengumuman reshuffle direspon secara negatif oleh para investor sehingga sebagian besar investor melakukan aksinya dengan menjual saham. Respon yang negatif ini dilatarbelakangi oleh sikap sebagian investor yang pesimis terhadap kemampuan tim ekonomi hasil reshuffle ini bila dunia usaha tidak mendukungnya dan peraturan juga tidak ditegakkan serta pemberlakuan kebijakan ekonomi tidak konsisten.

2. Menghitung market return harian (IHSG) untuk seluruh sampel selama periode pengamatan dan kemudian menyajikannya dalam 2 gambar grafik yang menunjukkan pola pergerakan market return harian selama periode pengamatan.

Tabel 2: Hasil Perhitungan Market Return Harian Selama Periode Pengamatan

\begin{tabular}{|c|c|c|c|c|c|c|c|c|}
\hline Tanggal & $t$ & $\mathrm{Rm}$ & Tanggal & $t$ & $\mathrm{Rm}$ & Tanggal & $\mathbf{T}$ & $\mathrm{Rm}$ \\
\hline 3-Oct-05 & -40 & 0.00383 & 26-Oct-05 & -23 & 0.00000 & 25-Nov-05 & -6 & -0.00350 \\
\hline 4-Oct-05 & -39 & 0.01639 & 27-Oct-05 & -22 & 0.00143 & 28-Nov-05 & -5 & 0.00620 \\
\hline 5-Oct-05 & -38 & 0.00262 & 28-Oct-05 & -21 & -0.00512 & 29-Nov-05 & -4 & 0.00113 \\
\hline 6-Oct-05 & -37 & -0.00696 & 31-Oct-05 & -20 & 0.00753 & 30-Nov-05 & -3 & 0.01327 \\
\hline 7-Oct-05 & -36 & -0.00157 & 1-Nov-05 & -19 & -0.00119 & 1-Dec-05 & -2 & -0.00025 \\
\hline 10-Oct-05 & -35 & 0.00743 & 9-Nov-05 & -18 & -0.01139 & 2-Dec-05 & -1 & 0.02102 \\
\hline 11-Oct-05 & -34 & 0.00258 & 10-Nov-05 & -17 & -0.00867 & 5-Dec-05 & 0 & 0.00104 \\
\hline 12-Oct-05 & -33 & -0.00240 & 11-Nov-05 & -16 & -0.01410 & 6-Dec-05 & +1 & 0.00255 \\
\hline 13-Oct-05 & -32 & -0.01128 & 14-Nov-05 & -15 & -0.01093 & 7-Dec-05 & +2 & 0.02486 \\
\hline 14-Oct-05 & -31 & 0.00566 & 15-Nov-05 & -14 & 0.00427 & 8-Dec-05 & +3 & 0.00604 \\
\hline 17-Oct-05 & -30 & -0.00603 & 16-Nov-05 & -13 & 0.00367 & 9-Dec-05 & +4 & 0.00151 \\
\hline 18-Oct-05 & -29 & 0.00530 & 17-Nov-05 & -12 & 0.00726 & 12-Dec-05 & +5 & 0.01288 \\
\hline 19-Oct-05 & -28 & -0.01821 & 18-Nov-05 & -11 & 0.02100 & 13-Dec-05 & +6 & 0.00598 \\
\hline 20-Oct-05 & -27 & -0.00047 & 21-Nov-05 & -10 & 0.00717 & 14-Dec-05 & +7 & -0.00703 \\
\hline 21-Oct-05 & -26 & 0.00052 & 22-Nov-05 & -9 & 0.00353 & 15-Dec-05 & +8 & -0.01513 \\
\hline 24-Oct-05 & -25 & -0.00268 & 23-Nov-05 & -8 & -0.00489 & 16-Dec-05 & +9 & -0.01085 \\
\hline 25-Oct-05 & -24 & -0.01017 & 24-Nov-05 & -7 & 0.01611 & 19-Dec-05 & +10 & 0.01653 \\
\hline
\end{tabular}


Berdasarkan Tabel 2 di atas, terlihat bahwa market return ada yang bernilai negatif dan positif. Market return yang bernilai negatif menunjukkan bahwa situasi perdagangan di bursa efek cenderung kurang bergairah atau tidak atraktif. Sebaliknya market return yang bernilai positif menunjukkan bahwa situasi perdagangan di bursa efek pada periode tersebut atraktif.

Berikut ini merupakan gambar dua grafik yang memperlihatkan pergerakan market return selama periode estimasi dan periode peristiwa. Gambar 2 secara umum menunjukkan gejolak yang tidak berarti, atau market return selama periode estimasi mengalami fluktuasi yang sangat kecil. Fenomena ini tidak dapat dilepaskan dari sikap kehatihatian para investor dalam mencermati perkembangan lingkungan bisnis yang secara umum tidak kondusif.

Sedangkan Gambar 3 menunjukkan pergerakan market return selama periode peristiwa yang sangat identik dengan pergerakan average actual return selama periode yang sama. Hal ini menunjukkan bahwa pergerakan market return yang terjadi di Bursa Efek Jakarta (BEJ) pada saat periode peristiwa sebagian besar dipengaruhi oleh pergerakan saham LQ 45 yang menjadi sampel penelitian.

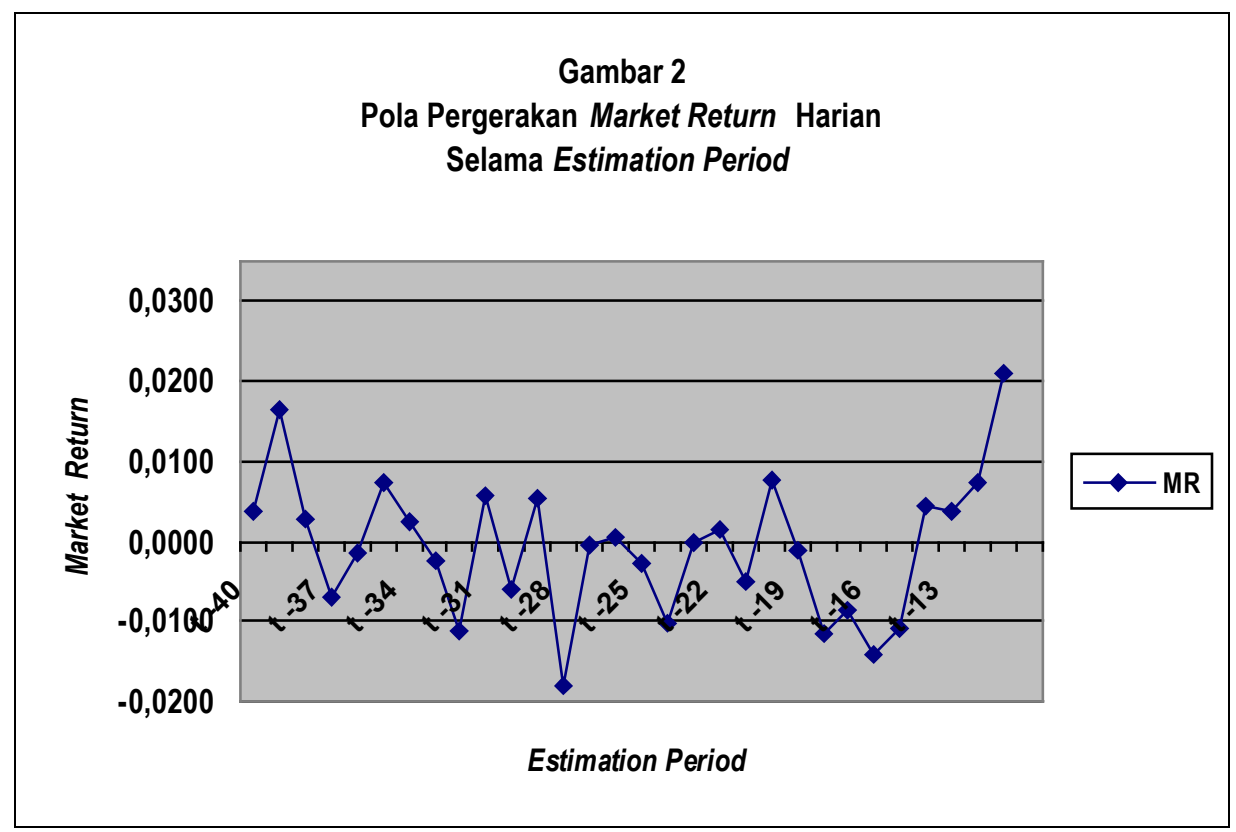




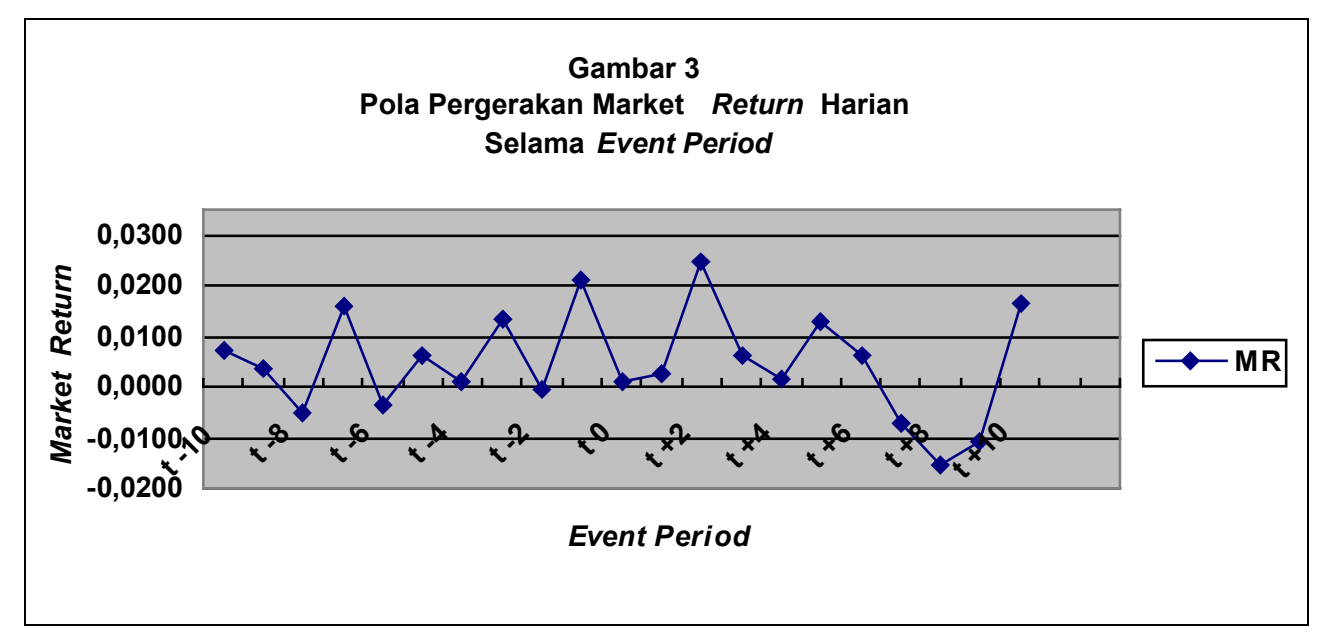

Tabel 3: Nilai Alfa dan Beta dari 45 Sampel Perusahaan

\begin{tabular}{|c|c|c|c|c|c|c|c|}
\hline No. & Kode & Alfa & Beta & No. & Kode & Alfa & Beta \\
\hline 1 & AALI & 0.002 & 0.552 & 24 & INTP & 0.004 & 1.589 \\
\hline 2 & ADHI & -0.001 & 1.427 & 25 & ISAT & 0.001 & 1.022 \\
\hline 3 & ADMG & -0.001 & 1.490 & 26 & JIHD & 0.000 & 0.745 \\
\hline 4 & ANTM & -0.003 & 0.555 & 27 & KIJA & -0.004 & 1.172 \\
\hline 5 & ASII & -0.001 & 1.818 & 28 & KLBF & 0.001 & 0.614 \\
\hline 6 & BBCA & -0.002 & 0.806 & 29 & LPBN & 0.001 & -0.030 \\
\hline 7 & BBRI & 0.001 & 1.177 & 30 & LSIP & 0.006 & 0.226 \\
\hline 8 & BDMN & -0.002 & 1.604 & 31 & MEDC & -0.004 & 0.999 \\
\hline 9 & BLTA & 0.005 & 0.730 & 32 & PGAS & 0.011 & 2.038 \\
\hline 10 & BMRI & -0.006 & 1.305 & 33 & PLAS & 0.001 & 0.208 \\
\hline 11 & BNBR & 0.004 & 1.767 & 34 & PNBN & -0.008 & 1.575 \\
\hline 12 & BNGA & -0.001 & 2.077 & 35 & PNLF & -0.005 & 2.570 \\
\hline 13 & BNII & -0.003 & 1.036 & 36 & PTBA & 0.002 & 1.313 \\
\hline 14 & BNLI & -0.005 & 0.737 & 37 & RALS & -0.002 & 1.480 \\
\hline 15 & BRPT & 0.003 & 3.616 & 38 & SMCB & -0.001 & 0.541 \\
\hline 16 & BUMI & -0.005 & 0.643 & 39 & SMRA & -0.003 & 0.936 \\
\hline 17 & CMNP & -0.001 & 1.177 & 40 & TINS & -0.003 & 1.026 \\
\hline 18 & ENRG & -0.003 & 0.693 & 41 & TKIM & -0.003 & 1.084 \\
\hline 19 & GGRM & -0.000098 & 0.762 & 42 & TLKM & 0.000 & 1.075 \\
\hline 20 & GJTL & -0.001 & 1.235 & 43 & UNSP & 0.003 & 0.901 \\
\hline 21 & INCO & -0.006 & 1.898 & 44 & UNTR & -0.002 & 1.402 \\
\hline 22 & INDF & 0.006 & 0.650 & 45 & UNVR & 0.003 & 0.962 \\
\hline 23 & INKP & -0.001 & 1.166 & & & & \\
\hline
\end{tabular}


3. Menghitung $\alpha$ (alfa) dan $\beta$ (beta) untuk setiap saham selama periode estimasi dengan menggunakan market model (Tabel 3). Beta ( $\beta$ ) yang diperoleh tersebut merupakan beta pasar untuk pasar modal yang perdagangannya tidak sinkron. Oleh karena itu untuk menghindari bias yang ditimbulkan dari fluktuasi nilai beta maka dipilih beta dengan periode estimasi yang mendekati event period, yaitu selama 30 hari pengamatan (Rustamadji, 2001: 39).

4. Menghitung average expected return untuk seluruh saham selama periode peristiwa (Tabel 4).

Tabel 4: Hasil Perhitungan Average Expected Return Saham Harian Selama Periode Peristiwa

\begin{tabular}{|c|r|c|c|c|c|}
\hline \multicolumn{2}{|c|}{ Sebelum Peristiwa } & \multicolumn{2}{c|}{ Saat Peristiwa } & \multicolumn{2}{c|}{ Sesudah Peristiwa } \\
\hline Hari ke & \multicolumn{1}{c|}{ Avg ER } & Hari ke & Avg ER & Hari ke & Avg ER \\
\hline $\mathrm{t}-10$ & 0.00783 & $\mathrm{t} 0$ & 0.00069 & $\mathrm{t}+1$ & 0.00245 \\
$\mathrm{~T}-9$ & 0.00359 & & & $\mathrm{t}+2$ & 0.02842 \\
$\mathrm{~T}-8$ & -0.00620 & & & $\mathrm{t}+3$ & 0.00652 \\
$\mathrm{~T}-7$ & 0.01824 & & & $\mathrm{t}+4$ & 0.00124 \\
$\mathrm{~T}-6$ & -0.00460 & & & $\mathrm{t}+5$ & 0.01447 \\
$\mathrm{~T}-5$ & 0.00670 & & & $\mathrm{t}+6$ & 0.00644 \\
$\mathrm{~T}-4$ & 0.00080 & & & $\mathrm{t}+7$ & -0.00869 \\
$\mathrm{~T}-3$ & 0.01493 & & & $\mathrm{t}+8$ & -0.01812 \\
$\mathrm{~T}-2$ & -0.00080 & & & $\mathrm{t}+9$ & -0.01314 \\
$\mathrm{~T}-1$ & 0.02395 & & & $\mathrm{t}+10$ & 0.01872 \\
\hline
\end{tabular}

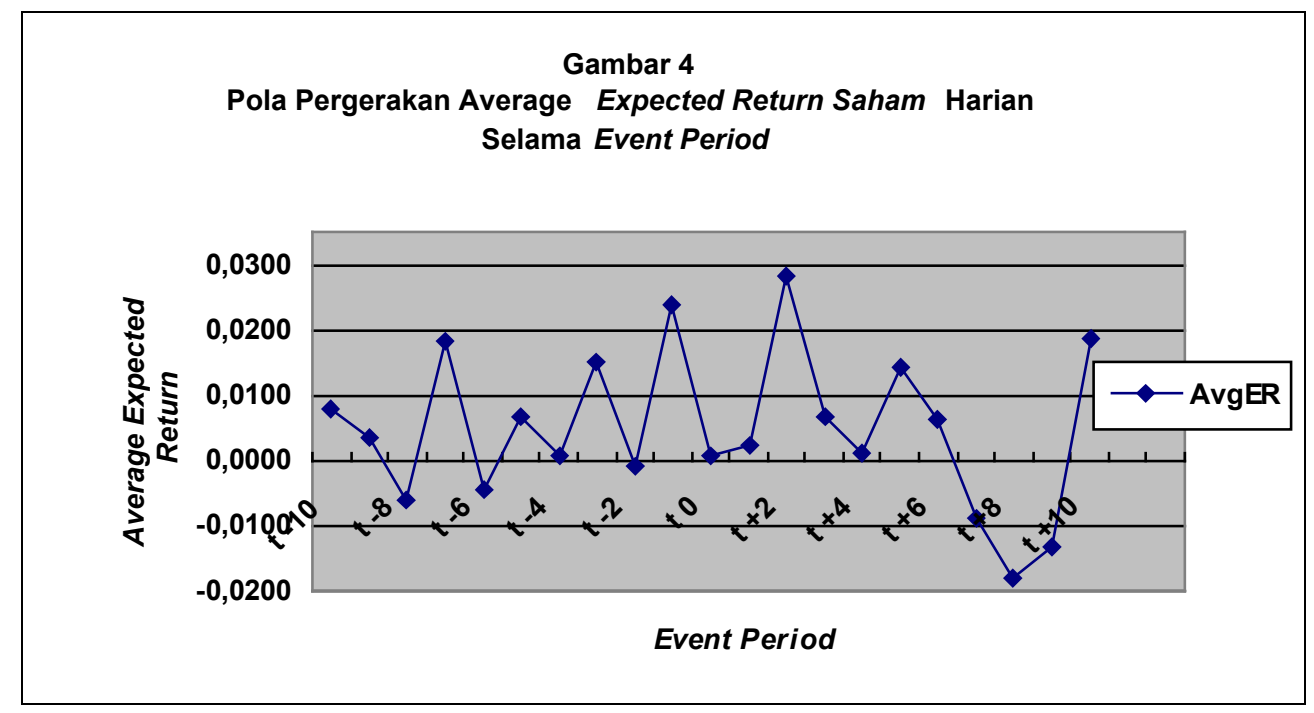


Gambar 4 tersebut memperlihatkan pergerakan average expected return saham harian selama periode peristiwa yang mengikuti atau identik dengan pergerakan market return harian selama periode peristiwa pada Gambar 3. Hal ini dimungkinkan karena beta sebagai nilai koefisien dari 45 saham yang diteliti, 97,78\% atau sebanyak 44 saham mempunyai nilai beta yang positif. Ini dapat diartikan bahwa saham-saham tersebut berkorelasi positif terhadap risiko pasar.

Secara keseluruhan dari 945 expected return selama periode peristiwa, 30,69\% atau sebanyak 290 mempunyai nilai expected return yang negatif, sedangkan 69,31\% atau sebanyak 655 mempunyai nilai positif. Hal ini menunjukkan bahwa investor cukup optimis dalam mengharapkan kemungkinan memperoleh keuntungan apabila melakukan investasi pada saham LQ 45 selama periode peristiwa.

5. Menghitung average abnormal return untuk seluruh saham selama periode peristiwa. Adapun berikut ini merupakan tabel hasil perhitungan average $a b$ normal return untuk seluruh sampel selama periode peristiwa.
Tabel 5 memperlihatkan average abnormal return saham harian selama periode peristiwa ada yang bernilai positif dan ada yang bernilai negatif. Average abnormal return yang positif dapat diartikan bahwa average actual return saham tersebut selama periode peristiwa lebih besar nilainya dibandingkan dengan average expected return yang diprediksi para investor. Average abnormal return selama periode peristiwa yaitu 21 hari bursa, 52.38\% atau sebanyak 11 hari bernilai negatif, termasuk pada saat peristiwa (t 0 ) terjadi average abnormal return yang bernilai negatif. Sedangkan average abnormal return yang bernilai positif sebesar 47,62\% atau sebanyak 10 hari bursa.

Berikut ini merupakan gambar yang menunjukkan pola pergerakan average abnormal return selama periode peristiwa. Selama 21 hari bursa, $47,62 \%$ atau sebanyak 10 hari bursa mengalami pergerakan average abnormal return yang positif (meningkat) dan $52.38 \%$ atau sebanyak 11 hari bursa mengalami pergerakan average abnormal return yang negatif (menurun).

Tabel 5: Hasil Perhitungan Average Abnormal Return Saham Harian Selama Periode Peristiwa

\begin{tabular}{|c|c|c|c|c|c|}
\hline \multicolumn{2}{|c|}{ Sebelum Peristiwa } & \multicolumn{2}{c|}{ Saat Peristiwa } & \multicolumn{2}{c|}{ Sesudah Peristiwa } \\
\hline Hari ke & AAR & Hari ke & AAR & Hari ke & AAR \\
\hline $\mathrm{t}-10$ & 0.00061 & $\mathrm{t} 0$ & -0.00657 & $\mathrm{t}+1$ & 0.00416 \\
$\mathrm{t}-9$ & 0.00195 & & & $\mathrm{t}+2$ & -0.00020 \\
$\mathrm{t}-8$ & 0.00447 & & & $\mathrm{t}+3$ & -0.00337 \\
$\mathrm{t}-7$ & -0.00607 & & & $\mathrm{t}+4$ & 0.00641 \\
$\mathrm{t}-6$ & -0.00042 & & & $\mathrm{t}+5$ & 0.00371 \\
$\mathrm{t}-5$ & -0.00431 & & & $\mathrm{t}+6$ & -0.00024 \\
$\mathrm{t}-4$ & -0.00122 & & & $\mathrm{t}+7$ & -0.00151 \\
$\mathrm{t}-3$ & -0.00388 & & & $\mathrm{t}+8$ & 0.00038 \\
$\mathrm{t}-2$ & 0.00701 & & & $\mathrm{t}+9$ & 0.00643 \\
$\mathrm{t}-1$ & 0.00547 & & & $\mathrm{t}+10$ & -0.00149 \\
\hline
\end{tabular}




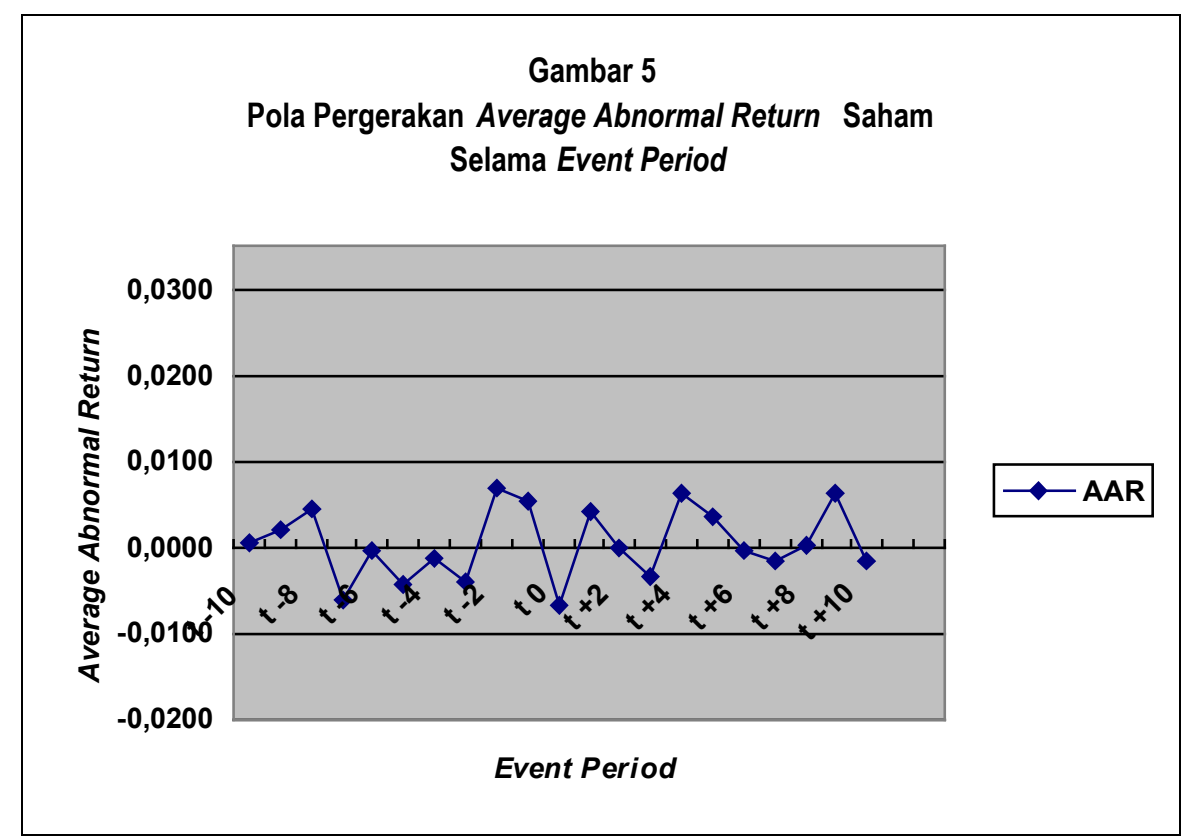

\section{Pengujian Hipotesis}

Hipotesis yang akan diuji dalam penelitian ini adalah:

$\mathbf{H}_{\mathbf{A}}$ : AAR $>0 ;$ average abnormal return lebih besar dari nol, artinya pasar modal bereaksi positif terhadap pengumuman reshuffle terbatas Kabinet Indonesia Bersatu

Hipotesis ini diuji dengan menggunakan uji t satu sisi sebelah kanan dan tingkat signifikansi $(\alpha)=10 \%, 5 \%$, dan $1 \%$ pada degree of freedom 44. Tabel 6 merupakan hasil pengujian statistik average abnormal return di sekitar tanggal pengumuman.

Ternyata hasil perhitungan dalam tabel 6 menunjukkan bahwa average abnormal return saham LQ 45 selama periode peristiwa, ada yang bernilai positif dan negatif. Average abnormal return, baik yang positif maupun negatif sama-sama muncul pada saat sebelum dan sesudah pengumuman reshuffle. Meskipun demikian beberapa average abnormal return yang muncul di sekitar tanggal pengumuman tersebut signifikan, yaitu pada hari $\mathrm{t}-9, \mathrm{t}-8$, $\mathrm{t}-2, \mathrm{t}-1, \mathrm{t}+1, \mathrm{t}+4, \mathrm{t}+5$ dan $\mathrm{t}+9$. Average abnormal return yang positif dan signifikan pada $\alpha=10 \%$ muncul pada 9 hari sebelum pengumuman reshuffle $(\mathrm{t}-9), 5$ hari dan 9 hari sesudah pengumuman $(\mathrm{t}+5$ dan $\mathrm{t}+9)$. Sedangkan average abnormal return yang positif dan signifikan pada $\alpha=5 \%$ muncul pada 8 hari dan 1 hari sebelum pengumuman reshuffle ( $\mathrm{t}-8$ dan $\mathrm{t}-1)$, dan 1 hari sesudah pengumuman $(\mathrm{t}+1)$. Selanjutnya average abnormal return yang positif dan signifikan pada $\alpha=1 \%$ muncul pada 2 hari sebelum pengumuman reshuffle $(\mathrm{t}-2)$, dan 4 hari sesudah pengumuman $(t+4)$. 
Tabel 6: Hasil Pengujian Average Abnormal Return Saham Harian di sekitar Tanggal Pengumuman

\begin{tabular}{|c|c|c|c|}
\hline $\begin{array}{c}\text { Hari } \\
\text { ke }\end{array}$ & AAR & $t_{\text {hitung }}$ & Keterangan \\
\hline$t-10$ & 0.00061 & 0.46581 & \\
$t-9$ & 0.00195 & 1.34263 & $*$ \\
$t-8$ & 0.00447 & 1.75157 & $*$ \\
$t-7$ & -0.00607 & -1.06461 & \\
$t-6$ & -0.00042 & -0.11656 & \\
$t-5$ & -0.00431 & -1.02173 & \\
$t-4$ & -0.00122 & -0.36933 & \\
$t-3$ & -0.00388 & -0.84994 & \\
$t-2$ & 0.00701 & 2.94536 & $* *$ \\
$t-1$ & 0.00547 & 1.96072 & $* *$ \\
$t 0$ & -0.00657 & -1.57464 & \\
$t+1$ & 0.00416 & 1.75758 & $*$ \\
$t+2$ & -0.00020 & 0.31587 & \\
$t+3$ & -0.00337 & -0.83908 & \\
$t+4$ & 0.00641 & 3.24025 & $*$ \\
$t+5$ & 0.00371 & 1.35721 & $*$ \\
$t+6$ & -0.00024 & 0.20592 & \\
$t+7$ & -0.00151 & -0.45536 & \\
$t+8$ & 0.00038 & 0.09252 & \\
$t+9$ & 0.00643 & 1.63452 & $*$ \\
$t+10$ & -0.00149 & 0.91171 & \\
\hline
\end{tabular}

Keterangan:

$*=$ signifikan pada $\alpha=10 \%(\mathrm{t}>1,303)$

$* *=$ signifikan pada $\alpha=5 \%(\mathrm{t}>1,684)$

$* * *=$ signifikan pada $\alpha=1 \%(\mathrm{t}>2,423)$

Hasil penelitian ditemukan terdapat average abnormal return yang positif dan signifikan muncul di sekitar tanggal pengumuman reshuffle. Reaksi pasar modal yang positif ini sesuai dengan signaling theory, yaitu pengumuman perombakan (reshuffle) anggota kabinet terbatas cenderung diartikan sebagai sinyal kepercayaan investor terhadap kinerja pemerintahan SBY - JK pada saat ini maupun di masa mendatang. Sinyal ini pada akhirnya akan berpengaruh positif terhadap pemegang saham yang dicermin- kan oleh naiknya harga saham. Respon yang positif ini dilatarbelakangi oleh sikap investor yang optimis terhadap kemampuan tim ekonomi hasil reshuffle ini dalam menyelesaikan masalah perekonomian pada saat ini dan di saat-saat mendatang. Hal ini dapat diartikan bahwa hipotesis nol, yang menyatakan bahwa pasar modal tidak bereaksi positif terhadap pengumuman perombakan (reshuffle) anggota kabinet terbatas ditolak.

Average abnormal return yang positif dan signifikan ini muncul pada saat 9 hari, 8 hari, 2 hari dan 1 hari sebelum pengumuman dikeluarkan $(\mathrm{t}-9, \mathrm{t}-8, \mathrm{t}-2, \mathrm{t}-1)$. Hal ini diduga karena sebagian investor telah memperoleh informasi pada saat sebelum tanggal pengumuman (ada kebocoran informasi) sehingga mereka mampu memberikan respon dengan cepat. Selain itu average abnormal return yang positif dan signifikan muncul pula pada saat 1 hari, 4 hari, 5 hari dan 9 hari sesudah pengumuman dikeluarkan $(\mathrm{t}+1, \mathrm{t}+4, \mathrm{t}+5$, dan $\mathrm{t}+9)$. Hal ini diduga karena sebagian investor lainnya terlambat mengetahui informasi ini sehingga investor lambat merespon informasi ini.

Meskipun ditemukan average abnormal return yang positif dan signifikan di sekitar tanggal pengumuman, tetapi pada saat tanggal pengumuman ( $t$ 0) muncul average abnormal return yang negatif. Munculnya reaksi pasar modal yang negatif pada saat pengumuman dikeluarkan ( $\mathrm{t} 0$ ) dan reaksi positif pada saat sebelum dan sesudah pengumuman dikeluarkan juga terjadi pada peristiwa yang serupa di era Presiden Megawati. Pasar bereaksi terlalu berlebihan terhadap berita Megawati yang akan menempatkan Boediono sebagai Menteri Keuangan dan Dorodjatun Kuntjoro Jakti sebagai Menko Perekonomian. Hal ini ditandai dengan indeks harga saham di bursa efek langsung melesat naik. Namun setelah berita itu benar-benar diumumkan, maka yang terjadi berlawanan, indeks langsung 
turun drastis (www.indonesia.nl: Selasa, 6 Desember 2005).

Berdasarkan hasil pengujian hipotesis maka dapat ditarik kesimpulan bahwa hipotesis alternatif diterima, yaitu pasar modal bereaksi positif terhadap pengumuman reshuffle terbatas Kabinet Indonesia Bersatu. Reaksi pasar modal yang positif ini dapat diartikan bahwa pasar menangkap informasi tentang prospek kinerja tim ekonomi yang baru yang terkandung dalam pengumuman tersebut. Hal ini dapat juga diartikan bahwa pengumuman perombakan (reshuffle) anggota kabinet terbatas memiliki kandungan informasi.

\section{SIMPULAN}

Pasar modal bereaksi positif dan signifikan terhadap pengumuman reshuffle anggota kabinet terbatas. Hal ini ditunjukkan dengan munculnya average abnormal return yang positif dan signifikan di sekitar tanggal pengumuman. Reaksi pasar modal yang positif ini sesuai dengan signaling. Selain itu average abnormal return yang positif dan signifikan ini muncul pada saat 9 hari, 8 hari, 2 hari dan 1 hari sebelum pengumuman muncul pada $\alpha=10 \%, 5 \%$, dan $1 \%$. Hal ini diduga karena sebagian investor telah memperoleh informasi pada saat sebelum tanggal pengumuman (ada kebocoran informasi) sehingga mereka mampu memberikan respon dengan cepat. Kemudian average abnormal return yang positif dan signifikan muncul pula pada saat 1 hari, 4 hari, 5 hari dan 9 hari sesudah pengumuman muncul pada $\alpha=10 \%, 5 \%$ dan $1 \%$. Hal ini diduga karena sebagian investor lainnya terlambat mengetahui informasi ini sehingga investor lambat merespon informasi ini.

Keterbatasan dalam penelitian ini adalah periode estimasi yang digunakan dalam penelitian ini kurang panjang, hanya 30 hari, sehingga menghasilkan perhitungan alfa $(\alpha)$ dan beta $(\beta)$ yang kurang tepat. Oleh karena itu pada penelitian yang menggunakan teknik studi peristiwa sebaiknya menggunakan periode estimasi yang lebih panjang dari 30 hari, misalnya 200 hari. Selain itu beta $(\beta)$ yang diperoleh merupakan beta $(\beta)$ pasar untuk pasar modal yang perdagangannya tidak sinkron sehingga kemungkinan besar beta $(\beta)$ mengandung bias. Oleh karena itu beta $(\beta)$ tersebut sebaiknya dikoreksi dengan menggunakan metode koreksi beta $(\beta)$ yang disebut Error Correction Model guna memperoleh hasil proyeksi expected return yang lebih tepat.

\section{DAFTAR PUSTAKA}

Asri, Marwan. (1996). US Multinationals' Stock Price Reaction to Host Country's Governmental Change (The Case of Prime Minister Takeshita's Resignation). Kelola, MM UGM - Yogyakarta, Vol. 5 (II): pp 126 - 137.

Brown S., and J. Warner. (1980). Measuring Security Price Performance. Journal of Financial Economics, Vol. 8, pp 205 - 258.

Gunawan, Barbara. (2004). Reaksi Pasar Modal Indonesia terhadap Peristiwa Politik Dalam Negeri (Studi Peristiwa Peledakan Bom di Gedung BEJ). Jurnal Akuntansi dan Investasi UMY Yogyakarta, Vol. 5 (I): pp 29 - 46.

Hartono, Jogiyanto. (2000). Teori Portofolio dan Analisis Investasi. Yogyakarta : BPFE.

Hidayat, Taufik (1999). Reaksi dan Aktivitas Volume Perdagangan Saham terhadap Peristiwa Pemilihan Umum Tahun 1999. Skripsi S-1 USD, Yogyakarta. 
SIIERGI Vol. 9 No. 2, JUNI 2007: $129-142$

Kritzman, Mark P. (1994). What Practitioners Need to Know ...about Event Studies. Financial Analysts Journal, pp 17 - 20.

Kurnia, Rene Julius. (2001). Event Study Pencabutan Fasilitas Mobnas terhadap Saham Industri Otomotif dan Komponennya pada Tahun 1998. Thesis S-2 MM FE UI, Jakarta.

Nugroho, Satya. (1999). Reaksi Harga Saham terhadap Sidang Istimewa MPR Tahun 1998. Skripsi S-1 USD, Yogyakarta

Nunuhitu, Pewi A.D. (1999). Reaksi Pasar Modal terhadap Pengumuman RAPBN, Event Study pada Pengumuman RAPBN 6 Januari 1998. Skripsi S-1 USD, Yogyakarta

Rustamadji, R. Gatot. (2001). Analisis Ekspektasi Investor di Bursa Efek Jakarta terhadap Peristiwa Politik, Event Study: Peristiwa Keputusan Memorandum oleh DPR dalam Kasus Buloggate dan Bruneigate. Usahawan No. 8 Thn XXX Agustus 2001.

Sulistyanto, H. Sri dan Meniek S. Prapti. (2003). Good Corporate Governance : Bisakah Meningkatkan Kepercayaan Masyarakat? Jurnal Ekonomi dan Bisnis - Ekobis, FE Universitas Islam Sultan Agung Semarang, Vol. 4/ No. 1/ Januari 2003.

Suryawijaya, A. Marwan dan F.A. Setiawan. (1998). Reaksi Pasar Modal Indonesia terhadap Peristiwa Politik Dalam Negeri (Event Study pada Peristiwa 27 Juli 1996). Kelola, $M M-U G M$ Yogyakarta, Vol. 7 (VIII): pp $137-153$.

Sari Suara Indonesia, 6 Desember 2005.

Suara Pembaruan, 11 Desember 2005.

Undang-Undang Republik Indonesia Nomor 8 Tahun 1995 Tentang Pasar Modal.

http:/www.tempointeraktif.com/ Selasa, 6 Desember 2005, Ambil Untung akan Warnai Sesi Pertama Bursa.

http:/www.fajar.co.id/ Kamis, 8 Desember 2005, "Wajah 'Kabinet Pelangi' Reshuffle SBY" 